FESIEE

Fundación Emilio Soldevilla de la Ecostigación y Desarmolio

\section{Management Letters / Cuadernos de Gestión}

\author{
journal homepage: http://www.ehu.eus/cuadernosdegestion/revista/es/
}

ISSN: 1131-6837 / e-ISSN: 1988-2157

\title{
Quality marks as an economic consolidation factor for rural tourism
}

\section{Las marcas de calidad como factor de consolidación económica del turismo rural}

\author{
Francisco Javier Ballina ${ }^{\star}$, Luis Valdés ${ }^{a}$ Eduardo Del Valle ${ }^{\mathrm{b}}$ \\ a Asturias Tourist Information System (SITA) - University of Oviedo. C / Luis Moya Blanco N. ${ }^{\circ}$ 261, Labor-City of Culture, 33203 Gijón (Spain) - lvaldes@uniovi.es \\ ${ }^{b}$ Asturias Tourist Information System (SITA) - University of Oviedo. C / Luis Moya Blanco N. . 261, Labor-City of Culture, 33203 Gijón (Spain) - valleeduardo@uniovi.es
}

* Corresponding author: Francisco Javier Ballina. Asturias Tourist Information System (SITA) - University of Oviedo. C / Luis Moya Blanco N. ${ }^{\circ} 261$, Labor-City of Culture, 33203 Gijón (Spain) - fballina@uniovi.es - https://orcid.org/0000-0001-7553-1066

\section{A R T I C L E I N F O}

Received 13 December 2018,

Accepted 10 September 2019

Available online 28 April 2020

DOI: $10.5295 / \mathrm{cdg} .181066 \mathrm{fb}$

JEL CODE: Q56, L83

\begin{abstract}
A B S T R A C T
The economic viability of the companies is a more significant gap in rural tourism. The quality standards can be a new instrument to help consolidate rural businesses, because of its positive direct and indirect effects: improve professionalism, increase the size of rural companies, protect the architecture and traditional culture, and facilitate segments of tourists of smaller size but of higher economic value.

However, the interest of rural businesspeople for rural quality marks will depend on the economic benefits that they provide, at least to initially support the investment and costs of implementation.

The article reviews the literature and its findings on the perceived benefits of quality standards, paying particular attention to rural accommodation. The research develops an empirical work with an extensive database. It contained the economic results obtained by a set of rural hotels in a specific region of Spain. These rural accommodations operate with a public quality standard called "Casonas Asturianas" (Old Asturian Palaces).

The results provide evidence about the relationship between the quality rural standard and the economic performance of the hotels. Also, the conclusions suggest the presence of some nuances in the self-selection bias, explicitly referring to high season tariffs.
\end{abstract}

Keywords: Rural Tourism, Quality, Performance, Standards, Sustainability.

\section{R E S U M E N}

El Turismo Rural tiene, como uno de sus principales gaps, la viabilidad económica continuada de sus empresas. En esta línea, Las normas de calidad rural pueden ser un instrumento interesante para facilitar la consolidación del negocio, dado que tienen efectos directos e indirectos positivos integrales. Así, entre otros, mejoran la profesionalización y el tamaño de las empresas rurales, ponen en valor la arquitectura y cultura tradicional y facilitan segmentos de turistas de menor tamaño pero mayor valor económico. Ahora bien, el interés de los empresarios rurales por las marcas de calidad rural dependerá de los beneficios económicos que les aporten, al menos para soportar inicialmente la inversión y costes de su implantación.

El artículo hace una revisión de la literatura sobre los beneficios aportados por las certificaciones de calidad en el turismo. E incorpora un trabajo empírico, con una extensa base de datos, sobre los resultados económicos obtenidos por un conjunto de hoteles rurales en una región específica de España. Se trata de alojamientos rurales que funcionan con una marca de calidad turística pública denominada "Casonas Asturianas" (antiguos palacios rurales).

Los resultados aportan evidencia sobre la existencia de una relación directa entre la marca de calidad y los resultados del hotel. Además, las conclusiones sugieren la existencia de algunos matices en el sesgo de autoselección, refiriéndose específicamente a las tarifas de temporada alta.

Palabras clave: Turismo Rural, Calidad, Beneficios, Normas, Sostenibilidad. 


\section{INTRODUCTION}

Rural Tourism (TR) is a catalyst for economic and social development in the rural environment (Guzmán-Parra et al. 2015). It allows valuing the heritage, its restoration, the preservation, and strengthening of the natural environment (Besteiro 2006). Originally, Rural Tourism was an activity complementary to the agriculture and livestock, but the successive economic crises convert to tourism in an economic priority in rural areas (Ballestero et al. 2014; Giaoutzi 2017).

In Europe, and particularly in Spain, great public efforts have been made to combat the decline of agricultural and livestock activity in the rural environment through a substantial boost from rural tourism (Komppula 2014), primarily through funds from the European Union, with programs like Proder and Leader.

Rural Tourism has overgrown in Spain (Cánoves et al. 2014): 5.5 hundred rural establishments and 1.2 million travelers in 2001, to reach 16.7 hundred establishments and 3.6 million travelers in 2017. Indeed, during the 2001/11 decade, both supply and demand have grown exponentially (Hernández et al. 2011). However, in recent years, evolution has slowed down, with ratios of decreasing occupancy and stay (Campón et al. 2017).

As Almonte and García (2016) indicate, the current situation in the rural world would be much worse if it had not been for the positive influence of rural tourism. It demonstrates the need to understand and work on the essential possibilities of change that tourism generates in rural economies (Roberts et al. 2017).

RT has grown significantly because:

(a) a growing segment of tourist value rural and natural spaces (Votsi et al. 2014; Villanueva et al. 2017);

(b) the transport networks improve too much, both terms of quality and price (Besteiro 2006);

(c) the real estate companies arrive at the rural inversions; and

(d) the eco-entrepreneurs come to rural areas (Komppula 2014; Villanueva et al. 2017).

This last factor is more important; it allows the professionalization of the managers and the growth in the size of the companies (Campón et al. 2017). Thus the Rural Tourism stops being a secondary and temporary business (Ballestero et al. 2014).

There is, in the academic literature, a full coincidence that the TR needs to assume significant changes (Campón et al. 2017), and that these must revolve around the term of sustainability (Gessa and Toledano 2011; Quesada and Sánchez 2014; Mateos 2015). Bernabé and Hernández, just like Mutalib et al. (2018) indicate, quality standards have positive effects on tourist satisfaction, and this, in turn, on business performance (Hernández and González 2009). The existence of such relationships makes the quality standards will be an essential motivation for rural tourism managers (Pinar and Ozgur 2007). Tourism is a point of balance between the social stability in the rural environment, the preservation of its environment, and the economic efficiency of tourism activity. Specifically, this paper aims to study the contribution of quality to the performance of rural tourism businesses. Indeed, the development of quality standards have reached unstoppably rural establishments (Hernández and González
2009) in Spain (Casadesús et al. 2010), but also in the international arena (Mutalib et al. 2018; Park et al. 2017; Ryglova et al. 2017).

The quality strategy contributes to sustainability:

(a) it increases the formation and structures the internal processes; and

(b) it is a clear sign of identity to the market (Tarí and Pereira 2012). Similarly, quality standards can provide an improvement in direct sustainability, through the implementation of specific criteria such as ISO 14001 (Boiral et al. 2018), and indirectly, through management quality standards such as ISO 9001 (Drossos et al. 2017).

However, most of the literature has focused on the case of large hotels, holiday or urban, on the one hand, and the high standards of ISO quality, in international research, and Q, in the Spanish case (Djofak 2012). There is, therefore, an essential gap in the literature, beyond some pioneering works, on the study of quality in rural tourism, and more specifically on the effects of specific rural quality brands (Solsona 2018).

The assumptions that underlie this paper are that rural tourism needs quality standards to provide economic benefits to rural tourism hotels. So they will be a precious incentive to consolidate it.

The study is carried out based on the rural quality brand called "Casonas Asturianas": small hotels (maximum of 20 rooms), located in rural areas, with traditional buildings and decoration (with heritage protection), and very oriented towards well-being, and service. This brand has served as a basis for developing other experiences in Latin America, such as the so-called "Mexican Treasury," and is being studied by tourism authorities in other countries such as Argentina, Chile, and Venezuela.

The "Casonas Asturianas Rural Quality Club" integrates all certified rural hotels to ensure coordinated management. Currently, a total of 57 rural hotels, compared to 33 in 2005, in squares are now 1244 rooms while in 2005 there were a total of 842 rooms.

\section{QUALITY CERTIFICATION AND RESULTS OF TOURISM COMPANIES}

The Signal Theory proposes that the availability of an exogenous quality certification by a hotel can function as a distinctive signal for the consumer (Kirmani and Rao 2000) as a selection risk reducer. Consequently, certification can:

1. Become a competitive advantage factor (Rusjan and Alic 2010).

2. Be an element of differentiation (Alonso and Rodríguez 2011; Walker and Johnson 2009).

3. Function as an attribute of choice of the accommodation itself (Mutalib et al. 2018).

The literature proposes that Quality Models have a clear economic objective (Asif et al. 2011) in the form of internal and external benefits (Alonso and Rodríguez 2011; Jan and Lin 2008; Sampaio et al. 2009; Tarí and Pereira 2012). 
From an internal perspective, quality certification has positive consequences on the operation of tourist accommodation:

1. Increase productivity and efficiency (Tarí et al. 2010),

2. Improve Resource Management (Dick 2009).

3. Allow reducing the errors of the provision of the service (Alonso et al. 2009).

4. Expedite the process documentation (Walker and Johnson 2009).

From the external perspective, the literature points out several positive benefits:

1. The attraction of new customers (Tarí et al. 2010; Walker and Johnson 2009).

2. Increase the number of repeated visits (Alonso et al. 2009; Walker and Johnson 2009).

3. Improvement in competitive position (Claver et al. 2006c).

4. Competitive survival guarantees for small independent hotels (Alonso and Rodríguez 2011).

5. Grow Sales and market share.

The implementation of a tourism quality standard requires a significant investment. That is why the main barrier to its adoption is the costs of implementation and maintenance, especially for small and medium enterprises (Chan 2008; Sampaio et al. 2009; Tarí et al. 2010), an especially important issue in the case of rural tourism.

Quality improvements in hotels produce higher customer satisfaction (Hernández and González 2009); this helps increase sales and market share. However, the results of the literature are still contradictory. Jan and Lin (2008) do not find a relationship, while other authors propose a positive correlation between quality certification and increased sales (Corbett et al. 2005; Dick et al. 2008; Nair and Prajogo 2009; Sharma 2005) or with the improvement of the market share (Sampaio et al. 2009).

The same contradiction exists in the literature that studies the relationship between quality certification and the improvement of business results. Most of the works conclude the absence of significant effects (Hernández and González 2009; Huertas 2005; Kang and Shang 2007; Martínez et al. 2009; Martínez and Martínez 2007). In others, a positive relationship is established with profitability (Lafuente et al. 2009) and with profit (Nair and Prajogo 2009).

Some works conclude a relationship with the employment rate (Claver et al. 2006b; 2006c; 2008; Tarí et al. 2009; Valdés and de la Ballina 2005). Other studies conclude that positive relationships with higher or prized pricing (Abrate et al. 2011; Han et al. 2009; Padilla et al. 2007; Valdés and de la Ballina 2005; Walker and Johnson 2009). Finally, it is possible to find works that combine both effects and conclude an increase in the total benefit of the hotel (Alonso et al. 2009; Bouranta et al. 2017; Claver et al. 2006a; 2008; Molina et al. 2009; Tarí et al. 2009; 2010).

Some literature contributions highlight other relevant issues about quality and performance. Thus, Dick et al. (2008) raise the existence of some self-selection: the largest hotel companies are the first to bet on quality certifications. Also that the positive results of the certification are more significant for the pioneer companies in certification (Benner and
Veloso, 2008; Corredor and Goñi 2011; Dick 2009; Naveh et al. 2004), since these decrease with time and with the increase of certified competitors (Kang and Shang 2007). But the importance of the benefits of certification is moderated by the credibility of the certifying body (Martín 2000). On the other hand, quality certification of a tourist accommodation can be a selection attribute for tourists (Mutalib et al. 2018), as well as a precise engine of improvement in the management of customers and employees (Del Río et al. 2017; Park et al. 2017).

In summary, rural hotels will have a greater interest in quality certifications when they provide a clear economic return. The research suggests than the union of internal and external benefits of certification has a positive effect on the hotel's performance. Also that it would be of an indirect type: the requirements of the quality standard perfect the processes by achieving a reduction of costs. Then, the quality standards contribute to improving the results, commercial and financial, and, therefore, the benefit of the rural hotels. However, the literature is scarce and without conclusive evidence.

\section{OBJECTIVE AND JUSTIFICATION OF HYPOTHESIS}

The objective is to demonstrate than the rural specifics standard improves the performance of rural hotels. But, differentiating two cases: commercial results (turnover) versus financial results (margins). An important issue in rural tourism, because it has problems with seasonality and short stays.

Some recent work indicates the existence of improvements in the commercial performance of tourist accommodation that have quality certifications (Alonso et al. 2009; Abrate et al. 2011; Martensen and Mouritsen 2013; Walker and Johnson 2009). This research considers the following elements of the commercial result: the occupancy rate, the average price, and, consequently, the annual turnover per room. The hypotheses related to the commercial performance raised are:

H1: Rural hotels certified with the rural standard obtain, per year, room billings higher than similar non-certified hotels.

H1a: Certified rural hotels operate with average annual prices higher.

$\mathrm{H} 1 \mathrm{~b}$ : Certified rural hotels operate at higher prices in all tourist seasons.

H1c: Certified rural hotels get higher occupancy rates.

The findings of the relationship between quality certification and benefits in tourist accommodation are controversial. Some authors conclude that there is no relationship between certifications and profit (Claver et al. 2006a) or that it is fragile and indirect (Harzallad et al. 2013). But the works carried out in Spain do establish a positive relationship between the Q quality certification and the operating profit per room and, consequently, the total gross profit (Alonso et al. 2009; Bouranta et al. 2017; Claver et al. 2008; Molina et al. 2009; Tarí et al. 2009; 2010). What can lead to intuit that the differences are a consequence of the typology of quality standards studied, ISO or Q, so it is worth considering the specific case of rural quality brands? The hypotheses related to the benefit are: 
H2: Rural hotels certified with the regional brand obtain a better annual evolution in gross operating profits compared to non-certified hotels.

H2a: Certified rural hotels get a better evolution in their annual profitability rates.

H2b: Certified rural hotels have a better annual evolution in their cost structure.

Figure 1 represents the scheme of predicted relationships between the work hypotheses.

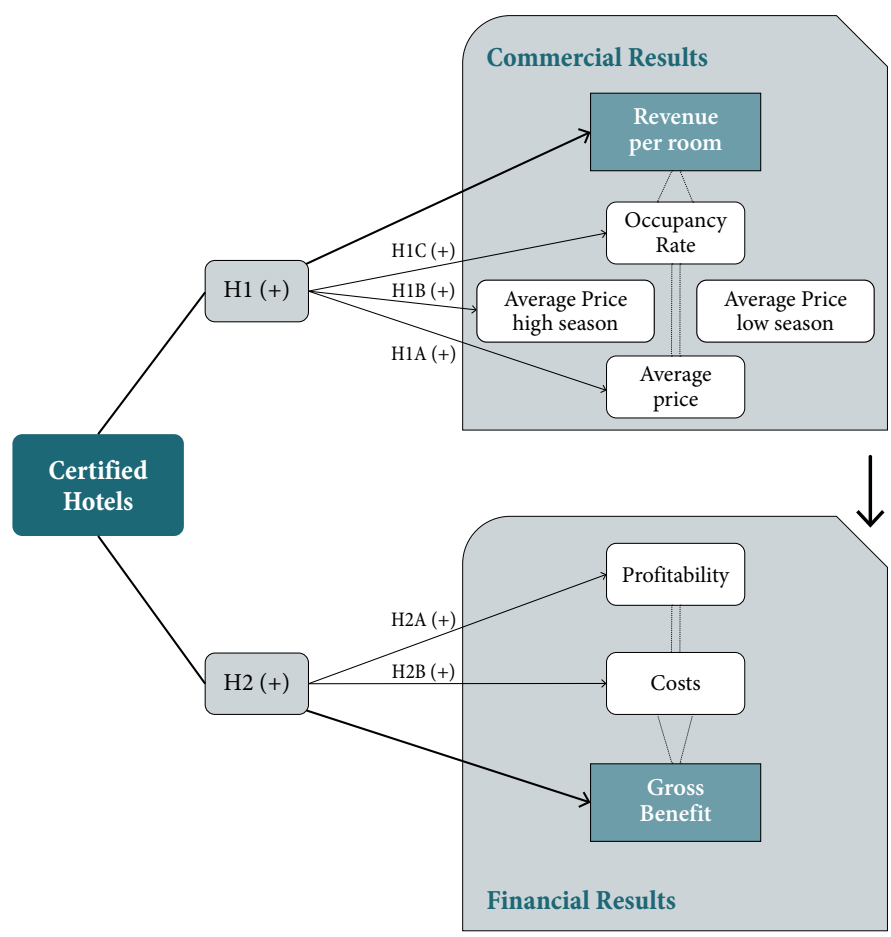

Figure 1

Expected relationships between the outcome variables according to the hypothesis set.

Source: Own elaboration.

\section{METHODOLOGY AND RESULTS OF RESEARCH}

The work uses data from the Asturias Tourist Information System (SITA), a public entity that collects quantitative information in the tourism sector in the region since 1997. Correctly, the study calls "Demand Survey": an annual survey of the directors of the hotels from 2005 to 2015 - this survey ceased to be carried out as of that year. The database has selected the cases corresponding to rural hotels of categories 1,2 and 3 stars, to achieve the necessary homogeneity in the type of business and the market of certified and non-certified hotels with the rural quality brand "Casonas Asturianas" (a similar approach with the ISO standard has been carried out by Wu and Chen 2011). Also, the database has used only those hotels that provided complete information on their economic results, to improve the quality of the analysis and results.
The research used two types of variables: commercial and financial results. Concretely, six variables represent the commercial results and three variables the financial results. Also, there are two classification variables: whether or not the hotel is certified (with the rural quality mark) and the number of stars (see Table 1).

Table 1

Variables of the statistical model.

\begin{tabular}{|c|c|c|c|}
\hline Number & Type & Variables & Character \\
\hline \multirow{6}{*}{$6 \mathrm{v}$} & \multirow{6}{*}{$\begin{array}{l}\text { Annual } \\
\text { evolution of } \\
\text { economic ratios }\end{array}$} & $\begin{array}{l}\text { OCRA: Occupancy } \\
\text { rate }\end{array}$ & 2.1 Commercial \\
\hline & & SALTO: Total sales & 2.2 Commercial \\
\hline & & $\begin{array}{l}\text { PRIME: Average } \\
\text { price }\end{array}$ & 2.3 Commercial \\
\hline & & $\begin{array}{l}\text { PROFIT: } \\
\text { Profitability }\end{array}$ & 3.1 Financial \\
\hline & & COST: Costs & 3.2 Financial \\
\hline & & BENEFI: Benefits & 3.3 Financial \\
\hline \multirow{3}{*}{$3 \mathrm{v}$} & \multirow{2}{*}{ Prices } & $\begin{array}{l}€ \text { PRIHIS: Average } \\
\text { Price high season }\end{array}$ & 2.4 Commercial \\
\hline & & $\begin{array}{l}€ \text { PRILOS: Average } \\
\text { Price low season }\end{array}$ & 2.5 Commercial \\
\hline & Income & $\begin{array}{l}€ B R O O M \text { : Revenue } \\
\text { per room }\end{array}$ & 2.6 Commercial \\
\hline \multirow{2}{*}{$2 \mathrm{v}$} & Certified hotel & $\begin{array}{l}\text { CERTI: Casona } \\
\text { certified hotel yes } \\
\text { or no }\end{array}$ & 1.1 Classification \\
\hline & Category & $\begin{array}{l}\text { CATE: Number of } \\
\text { Stars (1 to } 3)\end{array}$ & 1.2 Classification \\
\hline
\end{tabular}

Source: Own elaboration.

The data of the first variables group (annual evolution of economic ratios) worked with a Likert Scale (0 to 10). They measure the opinion of hotel managers on the degree of worsening or year-on-year improvement in each of the types of results. According to the research hypothesis, it should exist a better evolution to all variables in the certified hotels: higher in occupancy rate, total sales, the average price per room, profitability and profit; and lower in hotels certified in operating costs.

The following three variables, of commercial results, are of numerical scale. They measure the average in euros of the room price (double with breakfast) in the high and low tourist season and the billing per room (eliminating the billing in catering and other services). The work hypotheses expect a higher value for these variables in certified hotels.

Finally, there are two classification variables for rural hotels: a nominal variable that indicates whether the hotel is certified, and an ordinal variable that represents the category in stars. The first 
variable segments the Statistical models (certified versus non-certified rural hotels); the second variable moderate the Statistical effects (if the highest category produces better performance).

The database integrates the variables for the set of years. That is, it operates transversely. This decision is taken to have a sufficient number of hotel data, uniquely certified hotels. The work database has 691 data entries, $15 \%$ of which correspond to hotels certified with the rural brand. Two initial statistical checks validate the cross-sectional nature of the database. Kendall's coefficient $(\tau)$ contrasted six variables on the evolution of the economic results (they are ordinal variables). A proof o variance compared three price and billing variables (measures in $€$-they are numerical variables). The two indicators show differences between the years (significant above 0.005). However, these differences have the same form in different years. Consequently, the database has all variables consolidate (see Figure 2).
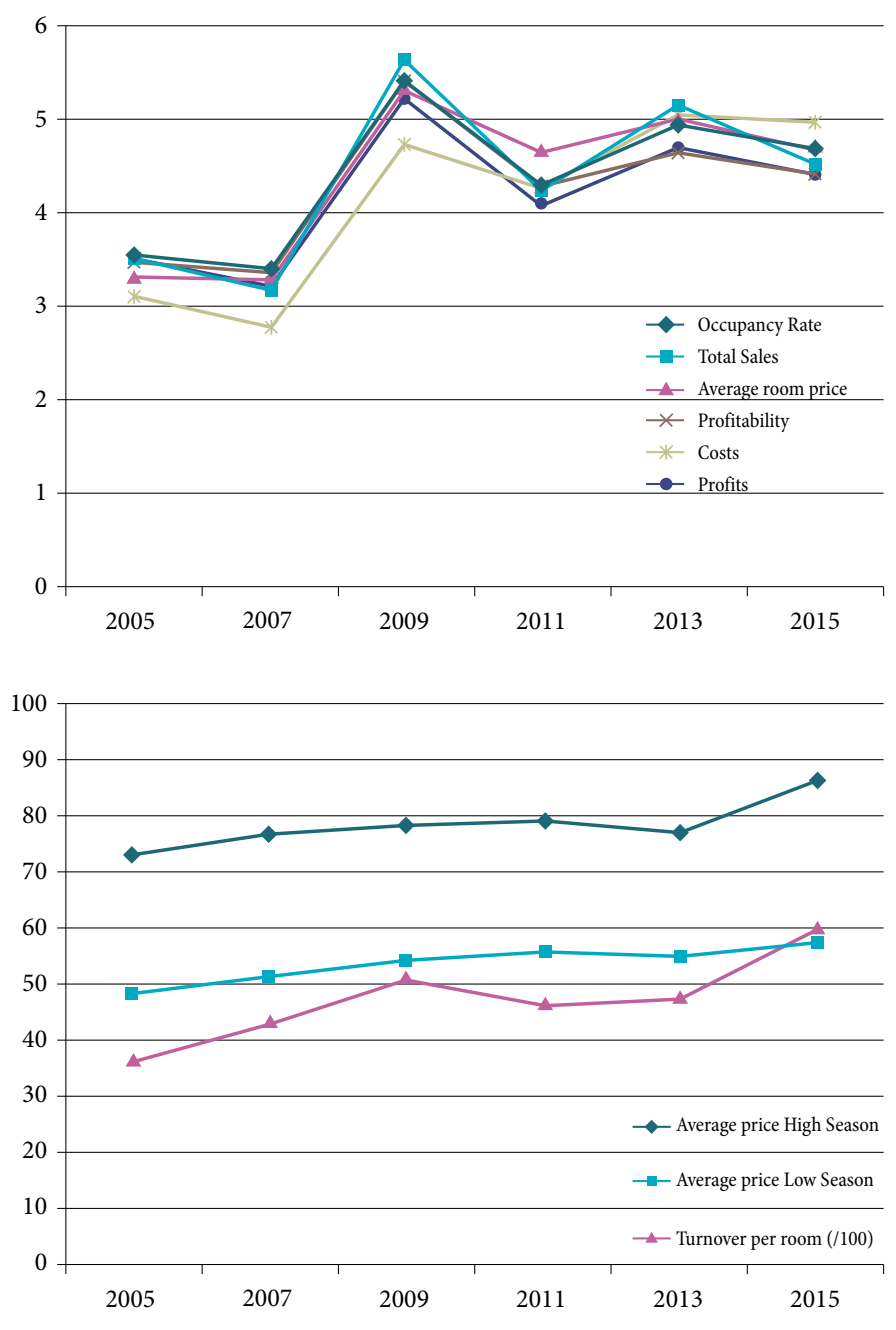

Figure 2

Evolution of the results variables

Source: Own elaboration.

The initial statistical results describe a neutral evolution in the economic outcomes during the period: the statistical means take values of the interval (4.5) for an ordinal scale of eleven points. Business results are slightly better than financial results. The price and billing variables have high variability. It is consistent with the character of rural-type hotels, star categories, and very different sizes, between small and medium-sized (see table 2).

Table 2

Descriptive Statistical Results

\begin{tabular}{lcccc}
\hline & $\mathbf{N}$ & Mean & Standard error & $\begin{array}{c}\text { Standard } \\
\text { Deviation }\end{array}$ \\
\hline OCRA & 691 & 4.47 & .060 & 1.565 \\
SALTO & 691 & 4.45 & .063 & 1.652 \\
PRIME & 691 & 4.46 & .048 & 1.253 \\
PROFIT & 678 & 4.35 & .054 & 1.397 \\
COST & 688 & 4.23 & .058 & 1.516 \\
BENEFI & 688 & 4.28 & .055 & 1.430 \\
€ PRIHIS & 688 & 78.9849 & .055 & 25.74027 \\
€ PRILOS & 687 & 53.9592 & .055 & 17.40530 \\
€BROOM & 691 & 4776.29 & .152 & 5214.480 \\
\hline SOUKCe: OWn & $665 t$ & & &
\end{tabular}

Source: Own elaboration.

Several T-Test tests study the economic results of the two leading causes of work (hotels certified against non-certified ones) (see Table 3). The inter-annual evolution of the economic ratios is significantly better in all cases for certified hotels: $12 \%$ in profitability; $11.2 \%$ in benefits; $10.7 \%$ in occupancy rate; $10.3 \%$ in sales; $7.6 \%$ in the average price. The case of costs is different since its significance does not exceed the required 0.05 .

The average selling prices of the room (in $€$ ) are much higher for certified hotels: $25.9 \%$ in the high season and $34.6 \%$ in the low season. But the best results for approved hotels are those of the average turnover per room: $52 \%$ above the average for certified hotels, $9.4 \%$ below the average for non-certified hotels.

Initially, several hypotheses are accepted:

1. Certified rural hotels have commercial ratios higher than non-certified: H1, H1A, H1B, and H1C hypotheses.

2. Certified rural hotels have higher financial results rates: profitability and benefit, hypotheses $\mathrm{H} 2$, and $\mathrm{H} 2 \mathrm{a}$.

3. The higher cost control of certified rural hotels cannot be confirmed or rejected, due to low statistical significance: $\mathrm{H} 2 \mathrm{~B}$ hypothesis.

A single analysis model integrated all sets of economic performance variables - also, a dummy variable enters in a logit model: certified or non-certified rural hotel. The correlation table shows the existence of a multicollinearity restriction, which requires the selection of variables that correlate greater than 0.7 in absolute value (Charity 1998) (see table 4). 
Table 3

T-tests of independent samples of Hotels yes and non-certified.

\begin{tabular}{lccccccc}
\hline & $\begin{array}{c}\text { Levene's Test } \\
\text { for Equality } \\
\text { of variances }\end{array}$ & & \multicolumn{5}{c}{ t-test for Equality of Means } \\
\cline { 2 - 8 } & F & Sig. & $\mathbf{t}$ & df & $\begin{array}{c}\text { Sig. } \\
(\text { 2-tailed) }\end{array}$ & $\begin{array}{c}\text { Mean } \\
\text { Difference }\end{array}$ & $\begin{array}{c}\text { Std. Error } \\
\text { Difference }\end{array}$ \\
\hline OCRA & & & -3.233 & 134.663 & .002 & -.572 & .177 \\
SALTO & & & -2.974 & 136.609 & .003 & -.545 & .183 \\
PRIME & & & -4.080 & 134.914 & .000 & -.574 & .141 \\
PROFIT & & & -3.782 & 128.991 & .000 & -.613 & .162 \\
COST & & & -1.950 & 140.530 & .053 & -.318 & .163 \\
BENEFI & & & -3.393 & 131.308 & .001 & -.570 & .168 \\
$€$ PRIHIS & 15.069 & .000 & -8.055 & 686 & .000 & -21.19239 & 2.63089 \\
$€$ PRILOS & 23.960 & .000 & -13.288 & 685 & .000 & -22.05481 & 1.65979 \\
$€$ BROOM & 12.291 & .000 & -5.411 & 689 & .000 & -2941.959 & 543.743 \\
\hline
\end{tabular}

Table 4

Correlation Matrix.

\begin{tabular}{|c|c|c|c|c|c|c|c|c|}
\hline & SALTO & PRIME & PROFIT & $\cos T$ & BENEFI & $\begin{array}{c}€ \\
\text { PRIHIS }\end{array}$ & $\begin{array}{c}€ \\
\text { PRILOS }\end{array}$ & $\begin{array}{c}€ \\
\text { BROOM }\end{array}$ \\
\hline \multirow{2}{*}{ OCRA } & $.831^{* *}$ & $.554^{* *}$ & $.760^{* *}$ & $.463^{* *}$ & $.712^{* *}$ & $.118^{* *}$ & $.161^{* *}$ & $.150^{* *}$ \\
\hline & .000 & .000 & .000 & .000 & .000 & .002 & .000 & .000 \\
\hline \multirow{2}{*}{ SALTO } & 1 & $.610^{* *}$ & $.755^{* *}$ & $.496^{* *}$ & $.775^{* *}$ & $.103^{* *}$ & $.139^{* *}$ & $.156^{* *}$ \\
\hline & & .000 & .000 & .000 & .000 & .007 & .000 & .000 \\
\hline \multirow{2}{*}{ PRIME } & & 1 & $.692^{* *}$ & $.555^{* *}$ & $.595^{* *}$ & .057 & $.164^{* *}$ & .056 \\
\hline & & & .000 & .000 & .000 & .133 & .000 & .141 \\
\hline \multirow{2}{*}{ PROFIT } & & & 1 & $.517^{* *}$ & $.778^{* *}$ & $.106^{* *}$ & $.174^{* *}$ & $.152^{* *}$ \\
\hline & & & & .000 & .000 & .006 & .000 & .000 \\
\hline \multirow{2}{*}{ COST } & & & & 1 & $.587^{* *}$ & $.134^{* *}$ & $.161^{* *}$ & $.082^{*}$ \\
\hline & & & & & .000 & .000 & .000 & .032 \\
\hline \multirow{2}{*}{ BENEFI } & & & & & 1 & $.091^{*}$ & $.140^{* *}$ & $.112^{* *}$ \\
\hline & & & & & & .017 & .000 & .003 \\
\hline \multirow{2}{*}{ €PRIHIS } & & & & & & 1 & $.707^{* *}$ & $.347^{* *}$ \\
\hline & & & & & & & .000 & .000 \\
\hline \multirow{2}{*}{$€$ PRILOS } & & & & & & & 1 & $.317^{\star *}$ \\
\hline & & & & & & & & .000 \\
\hline$€ B R O O M$ & & & & & & & & 1 \\
\hline
\end{tabular}

Source: Own elaboration.
There are two groups of variables with multicollinearity problems:

1. The evolution of the average occupancy rate (OCRA), annual sales (SALTO), profitability (PROFIT), and hotel profit (BENEFI).

2. The high season price ( $€$ PRIHIS) and the low season price ( $€$ PRILOS) of the hotel.

The first group chooses the variable average occupancy rate (OCRA). A decision with basics: there are controversial results in the literature on this variable; and it is interesting to operate with a variable of commercial rotation, that complements the prices. Also, the value of the inflation factor of the variance (VIF) for the occupancy rate compared to the others is high $(4,098)$, which makes it easier to work with almost perfect multicollinearity.

VIF is lower $(2,008)$ in the second group of variables. So, the research proposes to make two different alternative logit models: one with the average price in the low season (€ PRILOS) and the other with the high season (€ PRIHIS).

In the logit models, the reference category is the two-star category. This choice makes sense because it is the most frequent category in certified hotels (see figure 3 ).

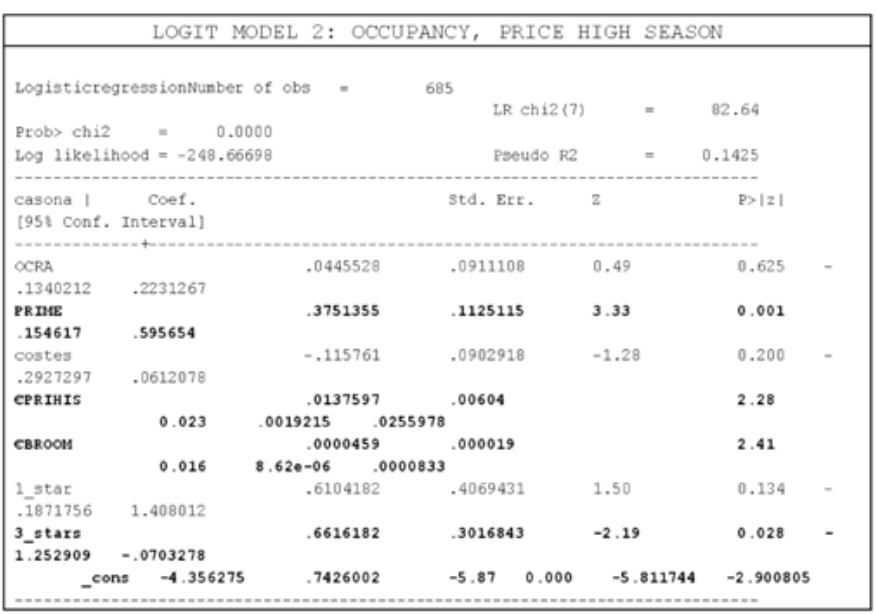

Figure 3

\section{Results of the logit models}

Source: Own elaboration.

The two models present the same significant variables, in a positive sense:

1. The average turnover per room ( $€$ BROOM), with levels of significance between $2-4 \%$ depending on the model.

2. The interannual evolution of the average sale price (PRIME), with levels of importance between 1-2\%.

3. The price per season (€ PRILOS or $€$ PRIHIS) is statistically significative in the two logit models.

But it is essential to observe how the logit 2 model considers the three-star category as a significant variable, with a negative explanatory sense of certification. That is the largest category of the hotel moderates the influence of the accreditation on prices in high season. 
The empirical results obtained with the logit models allow us to assume new evidence of the hotel quality certification on the economic and financial results of the rural business (see Chart 4):

1. The positive influence of the rural quality certification on the average turnover per room $(+\mathrm{H} 1)$.

2. The positive effect of rural quality certification on the average price per room $(+\mathrm{H} 1 \mathrm{~A})$.

3. The correspondence of the positive impact of the rural certification on the Price in both Low Season and High Season (+ H1B).

4. In the high season, the more important category of the rural hotel moderates the positive effect of the certification on the billing and prices $(-\mathrm{H} 1 \mathrm{~B})$.

However, the results of the statistical models do not allow establishing that certified rural hotels achieve improvements in occupancy rates. It prevents accepting the validity of the $\mathrm{H} 1 \mathrm{C}$ hypothesis. Also, the multicollinearity relations of the variable evolution of the occupancy rate (OCRA) with the benefits (BENEFI) and the profitability of the hotel (PROFIT) prevents the acceptance of hypotheses $\mathrm{H} 2$ and H2A. Similarly, the logit model doesn't validate the hypothesis about better performance of the evolution of costs in certified rural hotels (H2B).

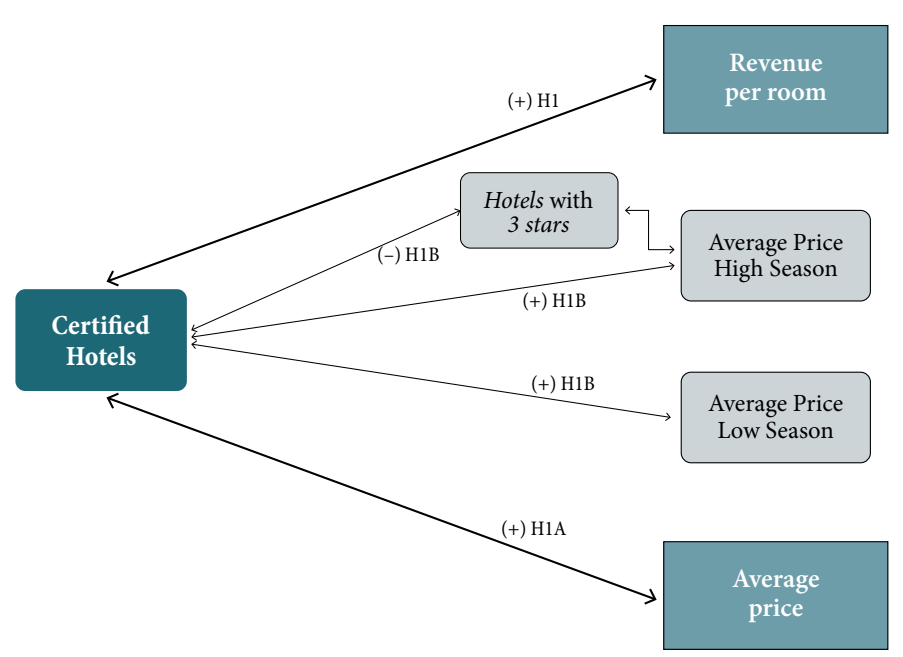

Figure 4

Hypotheses confirmed

Source: Own elaboration.

\section{CONCLUSIONS}

For rural accommodation, the costs of entry and maintenance in a quality certification system depend on the achievement of some management benefits. The results of this work indicate that quality certificates are signs of differentiation that customer's value, which is why certified hotels operate with higher average prices: premium prices. Also, the rural brand has a higher value in times of low demand. It allows accredited ac- commodation to avoid the use of price as a promotional tool, which, in the long term, would negatively affect the image of the destination and accommodation.

The certification produces a direct benefit for rural hotels: the increase in the average turnover per room. This increase is achieved with higher average prices since we cannot expect more significant customer attraction. On the other hand, the advantage in billing has more significant effects in the low season, which is one of the considerable gaps in tourism management. In summary, this benefit can offset the costs and efforts of rural quality certification.

However, for the quality certification to function as a signal, it must have high visibility. Being, in this case, a regional and public brand, the management of notoriety is in the hands of the hotel itself. Besides, there is the management of the number of certified hotels. The premium prices are possible with a limited number of approved rural hotels, then the generalization of the quality standard will reduce its positive effects.

The research is a step forward in the investigation of the positive effects of quality in rural tourism: the existence of premium prices. It is a significant incentive, but there is another: improvement in the sustainability of the rural environment. Because the quality standard requirements incorporate direct and also indirect sustainability measures, such as traditional buildings, furnishing, and decoration of the area, segments of tourists of higher quality, promotion of artisan and commercial activities linked to rurality. That is greater efficiency in the economy and rural, and consequently in the sustainability of the territory.

A significant limitation in rural tourism is the small number of accommodations that have tourist quality certifications. Also, other generic quality standards, such as ISO, are used. In this paper, we have tried to compensate for the problem of data minimalism through an accumulation of annual data.

Future research should improve using the data longitudinally, perhaps with the panel format. Also, other environmental quality systems, such as ISO 14001, could be incorporated. And, above all, add new variables for measuring the impact of rural-quality accommodation on the economy and sustainability of the rural environment in question.

\section{REFERENCES}

Abrate, G., Capriello, A., Fraquelli, G., 2011. When quality signals talk: evidence from the Turin hotel industry. Tourism Management, 32, 912-921.

Aguiló, E., Alegre, J., 2004. La madurez de los destinos de sol y playa. El caso de las Islas Baleares. Papeles de Economía Española, 102, 250270.

Almonte, J. M. J., García, F. J. P., 2016. Población y turismo rural en territorios de baja densidad demográfica en España. Boletín de la Asociación de Geógrafos Españoles, 71, 247-272.

Alonso, M.M., Rodríguez, J.M., 2011. Organizational behavior and strategies in the adoption of certified management systems. Journal of Cleaner Production, 19, 1455-1463.

Alonso, M.M., Rodríguez, J.M., Rubio, L., Celemín, M., 2009. Organizational impacts of quality certification on Business services. An analysis of the SMEs hotels. En: POMS 20th Annual Conference, Florida, USA. 
Asif, M., Searcy, C., Garvare, R., Ahmad, N., 2011. Including Sustainability Excellence Models. Total Quality Management \& Business Excellence, 22 (7), 773-786.

Ballestero, P. T., Romero, P. A., Serrano, L. G., 2014. Emprendimiento de la mujer en el ámbito rural: el turismo como motor de desarrollo. Esic Market, 149, 553-604.

Benner, M.J., Veloso, F.M., 2008. ISO 9000 practices and financial performance: A technology coherence perspective. Journal of Operations Management, 26, 611-629.

Bernabé, C. Y., Hernández, M. G., 2016. Turismo en Albarracín y Comarca. Acción pública local y dinámica reciente en clave de desarrollo turístico sostenible. Anales de Geografía de la Universidad Complutense, 36 (1), 73.

Besteiro, B., 2006. El Turismo Rural en Galicia. Análisis de su evolución en la última década. Cuadernos de Turismo, 17, 25-50.

Boiral, O., Guillaumie, L., Heras-Saizarbitoria, I., Tayo-Tene, C. V., 2018. Adoption and outcomes of ISO 14001: a systematic review. International Journal of Management Reviews, 20 (2), 411-432.

Bouranta, N., Psomas, E. L., Pantouvakis, A., 2017. Identifying the critical determinants of TQM and their impact on company performance: Evidence from the hotel industry of Greece. The TQM Journal, 29 (1), 147-166.

Campón, A.M., Hernández, J.M., Alves, H., 2017. Sustainable improvement of competitiveness in rural tourism destinations: The quest for tourist loyalty in Spain. Journal of Destination Marketing \& Management, 6, 252-266.

Cànoves, G., Garay, L., Duro, J. A., 2014. Turismo rural en España: Avances y retrocesos en los últimos veinte años. Papers de Turisme, 51, 7-21.

Caridad, J.M., 1998. Econometría: modelos econométricos y series temporales. Barcelona: Ed. Reverté.

Casadesús, M, Marimon, F., Alonso, M., 2010: The future of standardized quality management in tourism: evidence from the Spanish tourist sector. The Service Industries Journal, 30 (14), 2457-2474.

Chan, E.S.W., 2008. Barriers to EMS in the hotel industry. International Journal of Hospitality Management 27, 187-196.

Claver, E., Molina, J.F., Pereira, J., López, M.D., 2006c. Estrategias medioambientales y su influencia sobre el desempeño en el sector hotelero. Estudios Turísticos, 167, 37-54.

Claver, E., Pereira, J., Tarí, J.J., Molina, J.F., 2006a. La relación entre la gestión de la calidad y el rendimiento empresarial en el sector hotelero. Papers de Turisme, 40, 31-46.

Claver, E., Pereira, J., Tarí, J.J., Molina, J.F., 2008. TQM, managerial factors, and performance in the Spanish hotel industry. Industrial Management and Data Systems, 108 (2), 228-244.

Claver, E., Tari, J.J., Pereira, J., 2006b. Does quality impact on hotel performance? International Journal of Contemporary Hospitality Management, 18 (4), 350-358.

Corbett, C.J., Montes, M.J., Kirsch, D.A., 2005. The Financial Impact of ISO 9000 Certification in the United States: An Empirical Analysis. Management Science, 51 (7), 1046-1059.

Corredor, P., Goñi, S., 2011. TQM and performance: is the relationship so obvious? Journal of Business Research, 64, 830-838.

Del Río, J. A. J., Agüera, F. O., Cuadra, S. M., \& Morales, P. C., 2017. Satisfaction in border tourism: An analysis with structural equations. European Research on Management and Business Economics, 23 (2), 103-112.

Dick, G.P.M., 2009. Exploring performance attribution. The case of quality management standards adoption and business performance. International Journal of Productivity and Performance Management, $58(4), 311-328$
Dick, G.P.M., Heras, I., Casadesús, M., 2008. Shedding Light on causation between ISO 9001 and improved Business performance. International Journal of Operations and Production Management, 28 (7), 687-708.

Djofak, S., 2012. Análisis del impacto del sistema de calidad ISO 9001 y del sistema de calidad turística española en empresas y organizaciones turísticas: un estudio empírico en Baleares. Tesis, (Dr). Universidad de las Islas Baleares.

Drossos, D., Skordoulis, M., Chalikias, M., Kalantonis, P., Papagrigoriou, A., 2017. The impact of ISO 9001 quality management system implementation in tourism SMEs. En: Tourism, Culture, and Heritage in a Smart Economy, Cham: Springer, 145-157.

Elkington, J., 2018. 25 years ago I coined the phrase "Triple Bottom Line": Here's why its time to rethink it. Harvard Business Review, 25 June.

Gessa, A., Toledano, N., 2011. Turismo, emprendimiento y sostenibilidad en los espacios naturales protegidos: El caso de Andalucía-España. Estudios y Perspectivas en Turismo, 20 (5), 1154-1174.

Giaoutzi, M., 2017. Tourism and Regional Development: New Pathways. London: Ed. Routledge.

Guzmán-Parra, V.F., Quintana-García, C., Benavides-Velasco, C.A., Vila-Oblitas, J.R., 2015. Trends and seasonal variation of tourist demand in Spain: The rol of rural tourism. Tourism Management Perspectives, 16, 121-128.

Han, H., Hsu, L.J., Lee, J.S., 2009. An empirical investigation of the roles of attitudes toward green behaviors, overall image, gender, and age in hotel customers' eco-friendly decision-making process. International Journal of Hospitality Management, 28, 519-528.

Harzallad, A.M., Gutiérrez-Gutiérrez, L., Muñoz Rosas, J.F., 2013. Total Quality Management Practices, Competitive Strategies, and Financial Performance: The case of the Palestinian industrial SMEs. Total Quality Management \& Business Excellence, 25 (5-6), 635-649.

Hernández, R. M. H., González, B., 2009. Implicaciones de los Distintivos de Calidad: análisis en el Contexto del Turismo Rural Español. Revista Turismo \& Desenvolvimento, 12, 113-126.

Hernández-Mogollón, J. M., Campón-Cerro, A. M., Alves, H. M., 2011. The state of the art in research into rural tourism in Spain: an analysis from the perspective of marketing. Enlightening Tourism. A Pathmaking Journal, 1 (1), 31-61

Huertas, R., 2005. Eficiencia de la implantación de sistemas de calidad. Análisis de las empresas hoteleras. Estudios Turísticos 165, 33-55.

Jan, W.Y., Lin, C.I., 2008. An integrated framework for ISO 9000 motivation, depth of ISO 9000 implementation, and firm performance. The case of Taiwan. Journal of Manufacturing Technology Management, 19 (2), 194-216.

Kang, L., Shang, D., 2007. The difference in the perceived benefits between firms that maintain ISO certification and those that do not. International Journal of Production Research, 48 (5), 1881-1897.

Kirmani, A., Rao, A., 2000. No pain, no gain: a critical review of the literature on signaling unobservable product quality. Journal of Marketing 64, 66-79.

Komppula, R., 2014. The role of individual entrepreneurs in the development of competitiveness for a rural tourism destination-A case study. Tourism Management, 40, 361-371.

Lafuente, E., Bayo, A., García, M., 2009. ISO-9000 Certification and Ownership Structure: Effects upon Firm Performance. British Journal of Management, 21, 649-665.

Martensen, A., Mouritsen, J., 2013. Prioritizing Investments in marketing activities to improve business performance. Total Quality Management \& Business Excellence, 60 (5-6), 515-518. 
Martin, H., 2000. The certification mark as brand support? An evaluation by consumers. En: The Food Sector in Transition-Nordic Research. Proceedings of NJF Seminar, $\mathrm{n}^{\circ}$ 313, Copenhagen; Norwegian Agricultural Economics Research Institute.

Martínez, M., Choi, T.Y., Martínez, J.A., Martínez, A.R., 2009. ISO 9000/1994, ISO 9001/2000 and TQM: The performance debate revisited. Journal of Operations Management, 27, 495-511.

Martínez, M., Martínez, A.R., 2007. A triple analysis of ISO 9000 effects on company performance. International Journal of Productivity and Performance Management, 56 (5/6), 484-499.

Mateos, M.R., 2015. Turismo experiencial y gestión estratégica de recursos patrimoniales: un estudio exploratorio de percepción de productos turísticos en las Sierras Subbéticas cordobesas (Andalucía), Sevilla: Junta de Andalucía.

Molina, J.F., Tarí, J.J., Claver, E., López, M.D., 2009. Quality Management, Environmental Management and firm performance: a review of empirical studies and issues of integration. International Journal of Management Reviews, 11 (2), 197-222.

Mutalib, S. S. A., Razzaq, A. R., Hassan, A., 2018. A Review of Customer Service Quality in Malaysian Homestay Operation as the Strategies to Enhance Rural Area Economic Income. Advanced Science Letters, 24 (1), 534-536.

Nair, A., Prajogo, D., 2009. The internalization of ISO 9000 standards: the antecedent role of functionalist and institutionalist drivers and performance implications. International Journal of Production Research, 47 (16), 4545-4568.

Naveh, E., Marcus, A., Koo, H., 2004. Implementing ISO 9000: performance improvement by first or second movers. International Journal of Production Research, 42 (9), 1843-1863.

Padilla, C., Villalobos, P., Spiller, A., Henry, G., 2007. Preferencia y disposición del consumidor a pagar por un sello de calidad certificada: implicancias para productores de alimentos de origen campesino. Agricultura Técnica, 67 (3), 300-308.

Park, D. B., Kim, K. H., Choo, H., 2017. The development of quality standards for rural farm accommodations: A case study in South Korea. Journal of Hospitality \& Tourism Research, 41 (6), 673-695.

Pinar, M., Ozgur, C., 2007. The long-term impact of ISO 9000 certification on business performance: A longitudinal study using Turkish stock market returns. Quality Management Journal, 14 (4), 21-40

Quesada, F. B., Sánchez, M. D. S., 2014. Los parques nacionales españoles, catalizadores del turismo sostenible. Anuario Jurídico y Económico Escurialense, XLVII, 511-534.
Roberts, L., Hall, D., Morag, M., 2017. New Directions in Rural Tourism. London: Ed. Routledge.

Rusjan, B., Alic, M., 2010. Capitalizing on ISO 9001 benefits for strategic results. International Journal of Quality \& Reliability Management, 27, 756-778.

Ryglová, K., Rašovská, I., Šácha, J., 2017. Rural Tourism-Evaluating the Quality of Destination. European Countryside, 9 (4), 769-788.

Sampaio, P., Saraiva, P., Guimaraes, A., 2009. ISO 9001 certification research: questions, answers, and approaches. International Journal of Quality and Reliability Management, 26 (1), 38-58.

Sharma, D.S., 2005. The association between ISO 9000 certification and financial performance. The International Journal of Accounting, 40, 151-172.

Solsona, J., 2018. Calidad en la gestión de alojamientos turísticos rurales. Gestión Turística, 5, Edición Especial, 65-89.

Tarí, J.J., Claver, E., Pereira, J., Molina, J.F., 2009. Is it worthwhile to be a quality certified hotel? Evidence from Spain. International Journal of Quality and Reliability Management, 26 (9), 850-864.

Tarí, J.J., Claver, E., Pereira, J., Molina, J.F., 2010. Levels of quality and environmental management in the hotel industry: their joint influence on firm performance. International Journal of Hospitality Management, 29, 500-510.

Tarí, J. J., Pereira, J., 2012. Calidad y rentabilidad. Análisis del certificado Q en las cadenas hoteleras. Universia Business Review, 34, 52-67.

Valdés, L., De La Ballina, F.., 2005. La calidad en el turismo rural: el caso de las marcas de calidad regionales. Investigación y Marketing, 87, 43-48.

Villanueva-Álvaro, J. J., \& Mondéjar-Jiménez, J., 2017. Income profile of the Spanish self-employed workers. Tourism, Economy, and Environment: New trends and research perspectives, 165.

Votsi, N. E. P., Mazaris, A. D., Kallimanis, A. S., \& Pantis, J. D., 2014. Natural quiet: An additional feature reflecting green tourism development in conservation areas of Greece. Tourism Management Perspectives, 11, 10-17.

Walker, R.H., Johnson, L.W., 2009. Signaling intrinsic service quality and value via accreditation and certification. Managing Service Quality, 19 (1), 85-105.

Wu, I.W., Chen, J.H., 2011. Comparison between manufacturing companies that are ISO certified and those that are not certified using performance measurement Model. Total Quality Management \& Business Excellence, 22 (8), 869-890. 